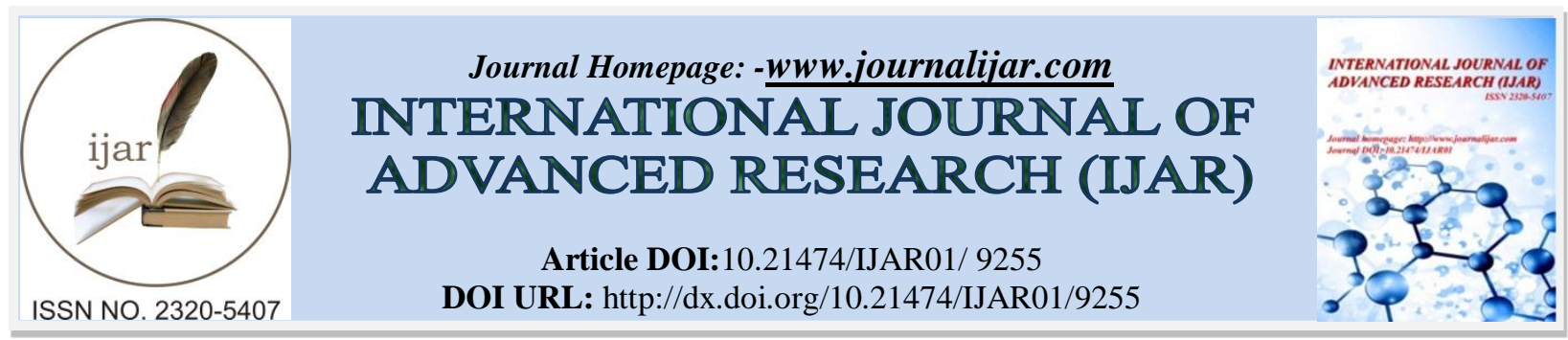

RESEARCH ARTICLE

\title{
DETERMINANTS OF ONION SELF-SUFFICIENCY IN SENEGAL: SITUATIONAL ANALYSIS OF THE SUBSECTOR.
}

Ngoné Fall beye ${ }^{1,2,3}$, Nicolas Cyrille Ayessou ${ }^{1}$, Michel Bakar Diop ${ }^{2,3}$, Saliou Ndiaye ${ }^{4}$ and Codou Mar Diop ${ }^{1}$

1. Polytechnic school, (ESP) / Center for Food Security and Functional Molecules Studies (CESAM-RESCIF), Cheikh Anta Diop University. Dakar, Senegal.

2. Training and Research Unit of Agricultural Sciences, Aquaculture and Food Technologies (UFR S2ATA).

3. Laboratory for Biological Sciences, Agronomy and Complex Systems Modelling (LaBAM) / UGB, SaintLouis, Senegal.

4. National Agronomic School / University of Thiès (ENSA / UT).

\section{Manuscript Info}

\section{Manuscript History}

Received: 10 April 2019

Final Accepted: 12 May 2019

Published: June 2019

\section{Key words:-}

Allium cepa L., Seasonality of production, Sectoring of production, Post-harvest treatments, Food security and processing.

\section{Abstract}

The production of onion has been steadily increasing in Senegal over the past ten years to reach a level never witnessed in 2016 (393,225 tons). Despite this bumper crop, the coverage of annual onion demand for domestic use (150 000 to 250000 tons) is still dependent on imports. The objective of this study is to identify the levers to consolidate the development of the onion subsector along the entire value chain and contribute to food security.

The analysis was conducted on the basis of interviews with the actors and a literature search.

The obstacles of food self-sufficiency that come out of this analysis are the:

Seasonality of crops;

Consumers' preference for imported onions deemed to be of superior quality to that of local onions;

Large post-harvest losses (5\% to $10 \%$ in the field, $20 \%$ to $40 \%$ respectively for three and six month storage) due to the lack of adequate storage structures;

Multiplicity of actors and the absence of well-structured marketing channels;

Lack of adequate technologies for agri-food processing.

Considering the constraints mentioned above, sectoring the production areas by period, and improving the storage and processing conditions are the keys solutions to onion self-sufficiency in Senegal.

Copy Right, IJAR, 2019,. All rights reserved.

\section{Introduction:-}

Agriculture, the flagship activity of the primary sector in Senegal, is an essential pillar of the economy. In fact, in 2015 the rural population accounted for 56.3\% (ANSD, 2013; FAO, 2017; FAOSTAT, 2016), of which 31\% (Luumpa, Kouassi, \& Chinganya, 2016) was agricultural and eco-active. Agriculture, particularly rain-fed and seasonal agriculture, contributed about $18 \%$ of GDP and is one of the key levers for ensuring food security.

Corresponding Author:-Ngoné Fall beye.

Address:-Polytechnic school, (ESP) / Center for Food Security and Functional Molecules Studies 
With this in mind, all agricultural programs developed by successive governments since the Agro-Sylvo Pastoral Orientation Act (LOASP) in 2004, have focused on the key vision of making agriculture the backbone nerve of economic and social development of Senegal. In addition, these strategic orientations are fully in line with the Millennium Development Goals (MDGs), specifically those related to the eradication of poverty (Cabral, 2012; Seck, 2013).

Among these agricultural programs, can be mentioned, the Plan for Return to Agriculture (REVA) in 2006, which then became ANIDA (National Agency of Insertion and Agricultural Development), the Great Agricultural Offensive for Food and Agriculture Abundance (GOANA) in 2008, and finally the Program of Recovery and Acceleration of the Agricultural Cadence in Senegal (PRACAS) in 2012. PRACAS, the agricultural component of Senegal's strategic development policy called the Emerging Senegal Plan (PSE), aims to ensure food selfsufficiency, reduce imports of staple foods, increase incomes and ultimately, reduce poverty.

Through targeted public programs, PRACAS gives priority to the development of the horticultural sub-industry. Horticulture, with high value-added crops, has been growing between 5\% and 10\% since 2004, (ANSD, 2016b; DH, 2015)and is the most dynamic sub-industry of Senegalese agriculture. This performance is mainly driven by the growth of the onion subsector, which accounted for $32 \%$ of the market gardening sector $(60 \%$ of the horticultural sub-industry) in 2015.

Despite these efforts to revitalize the onion subsector with an important increase in production, Senegal still depends on imports to cover consumer demand. This finding justifies the realization of this study whose objective is to identify the levers on which it is essential to foster the development of the onion subsector at all levels (diversify the supply, ensure better availability and accessibility of the onion) for onion self-sufficiency.

\section{Materials and Methods:-}

The methodological approach is based on meetings with key actors to analyse the evolution of onion production within the market gardening sector in Senegal and the evaluation of the different strategic orientations. The interviews were based on a questionnaire on the most cultivated varieties, agricultural practices, storage conditions, as well as the roles and impacts of governmental services 'actions in the organization of the subsector.

Three types of target population were selected for the administration of the questionnaires:

1. onion growers and farmers' organizations such as the Association of Market Gardeners of Niayes (AUMN), and the Association of Onion Producers of the Valley (APOV);

2. seed producers like Tropicasem, market leader, and research and development institutions such as the Center for Horticultural Development (CDH) and the Senegalese Institute for Agricultural Research (ISRA);

3. and finally the state services that are in charge of technical support, regulatory, commercial and statistical aspects, namely:

1. the National Land Development and Exploitation Company of the Senegal River Delta, the Senegal River Valley and the Falémé (SAED);

2. the Market Regulation Agency (ARM);

3. the Directorate of Internal Trade (DCI);

4. the National Agency for Statistics and Demography (ANSD).

The collection of information from the two farmers' organizations is conducted by focus groups. Three groups of ten producers are drawn by lot from each list of members of the AUMN and APOV. With each group, three waves of collective interview are carried out over three consecutive years (2014 to 2016). In total, sixty producers are interviewed for this study.

As for seed producers, research institutes and government departments, the collection of information was carried out through individual interviews with key stakeholders (managers, technical managers, sales managers, etc.).

The information collected is cross-referenced with that available on both national and international databases to ensure its validity.

The draw, the codification for the constitution of the database and the analysis of the latter are performed with the excel version 2016 software. 


\section{Results:-}

\section{Varieties, Periods and Cultivation Methods}

The onion, by its scientific name Allium cepa L. var Cepa, is a biennial plant belonging to the Alliaceae family and has been domesticated for the consumption of its bulb. Physiologically, the growth of the bulb being intrinsically dependent on the photoperiod, the varieties best adapted to the ecological conditions of West Africa are violet or white short day varieties (Abdou, Bakasso, Adam, Saadou, \& Baudoin, 2015; Hanelt, 2018; Kroll, 1994).

One of the most cultivated standard varieties is Galmi Violet, originating from Niger and introduced to Senegal in the 1970s (Currah, 2002). The results of research in Senegal have also resulted in the dissemination of improved new varieties (Table 1) (Dewez, Gerard, Delhove, \& Dramé, 2012; Niang, 2015; Tropicasem, 2014).

Table 1:-Classification of the most cultivated onion varieties in Senegal according to the growing season

\begin{tabular}{|c|c|c|c|c|}
\hline & \multicolumn{3}{|c|}{ Cold Season Crops (CSF) } & $\begin{array}{c}\text { Hot Season } \\
\text { Crops (CSC) }\end{array}$ \\
\hline & $\begin{array}{c}\text { Early Crops } \\
\text { (hasty) }\end{array}$ & $\begin{array}{c}\text { Full Season } \\
\text { Crops }\end{array}$ & $\begin{array}{c}\text { Medium late } \\
\text { Crops }\end{array}$ & Late Crops \\
\hline Variety & \multicolumn{3}{|c|}{ Sowing dates } \\
\hline & October & $\begin{array}{c}\text { November - } \\
\text { December }\end{array}$ & $\begin{array}{c}\text { January - } \\
\text { February }\end{array}$ & March - April \\
\hline Galmi Violet & $\mathbf{X}$ & $\mathbf{X}$ & $\mathbf{X}$ & $\mathbf{X}$ \\
\hline Orient & $\mathbf{X}$ & $\mathbf{X}$ & $\mathbf{X}$ & $\mathbf{X}$ \\
\hline $\begin{array}{c}\text { Texas Early Grandiol F1 } \\
\text { Passion, Goudaye, Goldor, Red }\end{array}$ & $\mathbf{X}$ & $\mathbf{X}$ & $\mathbf{X}$ & $\mathbf{X}$ \\
\hline Mercedes, Safari & $\mathbf{X}$ & & \\
\hline $\begin{array}{c}\text { Red Créole, Yakar, Rouge d'Amposta, } \\
\text { Jaune d'Espagnole, Gao }\end{array}$ & & $\mathbf{X}$ & & \\
\hline \multicolumn{2}{|c|}{} & & & $\mathbf{X}$ \\
\hline
\end{tabular}

According to the sowing dates (Table 1), two main production periods are observed in Senegal, namely:

1. the cold season period (CSF) from October to March includes early, mid-season and late-season crops;

2. the hot season period (CSC) from April to June includes late crops.

The classification of cultivation methods according to sowing dates is as follows:

Direct sowing or transplanting seedlings:

1. full-season crop with November-December sowing and mid-late crop with January-February sowing (CSF);

2. late crop, known as the off-season crop (CSC), with sowing between March and April.

\section{Bulblets seedling:}

Early crop, which is made only from bulblets, is a cold season crop (CSF).

The bulblets being produced the first year in April, only varieties of late culture are appropriate to obtain, in the first year, bulblets that are dried and stored. The latter are sown in October of the following year for bulb production. In the Senegal River Valley as well as in the Niayes, interviews with producers show that more than $90 \%$ of the interviewed producers practice an agricultural method based on seedling transplantation (APOV, 2015, 2016, 2017; AUMN, 2015, 2016, 2017).

The classification of production periods according to sowing dates (Table 1), shows that the most cultivated varieties (Galmi Violet, Orient F1 and Gandiol F1), are suitable for early, full-season, medium-late and late crops. In contrast, the Mercedes and Safari varieties are grown only in full season.

In addition, the lower cost of labor and the fewer constraints in terms of crop control and disease control that characterize seedling transplantation agriculture justify the dominance of this practice (Gourc, Monnier, \& Payet, 2007; PADEN, 2014). However, small quantities of bulblets are harvested in the Niayes area between late December and January. 


\section{Production Areas}

The cultivation of onions is practiced in all regions of Senegal. Nevertheless, production is mainly provided by the Senegal River Valley and the coastal strip called the "Niayes", extending from Dakar to Saint-Louis.

The production of onions thus contributes to the food security of agricultural households in all regions of Senegal, and particularly in the Niayes zone. Before the 2000 s, on average $60 \%$ of the national production was produced in this area (ANSD, 2016a; DH, 2016).

In fact, onion being a demanding crop in terms of water, light, and fertilization, the soil and hydro-geological characteristics of the Niayes area make it a favorite area. However, production increases are observed in the Koupango Valley, a special zone in the region of Fatick.

Figure 1 shows the geographical location of the various onion production areas in Senegal.

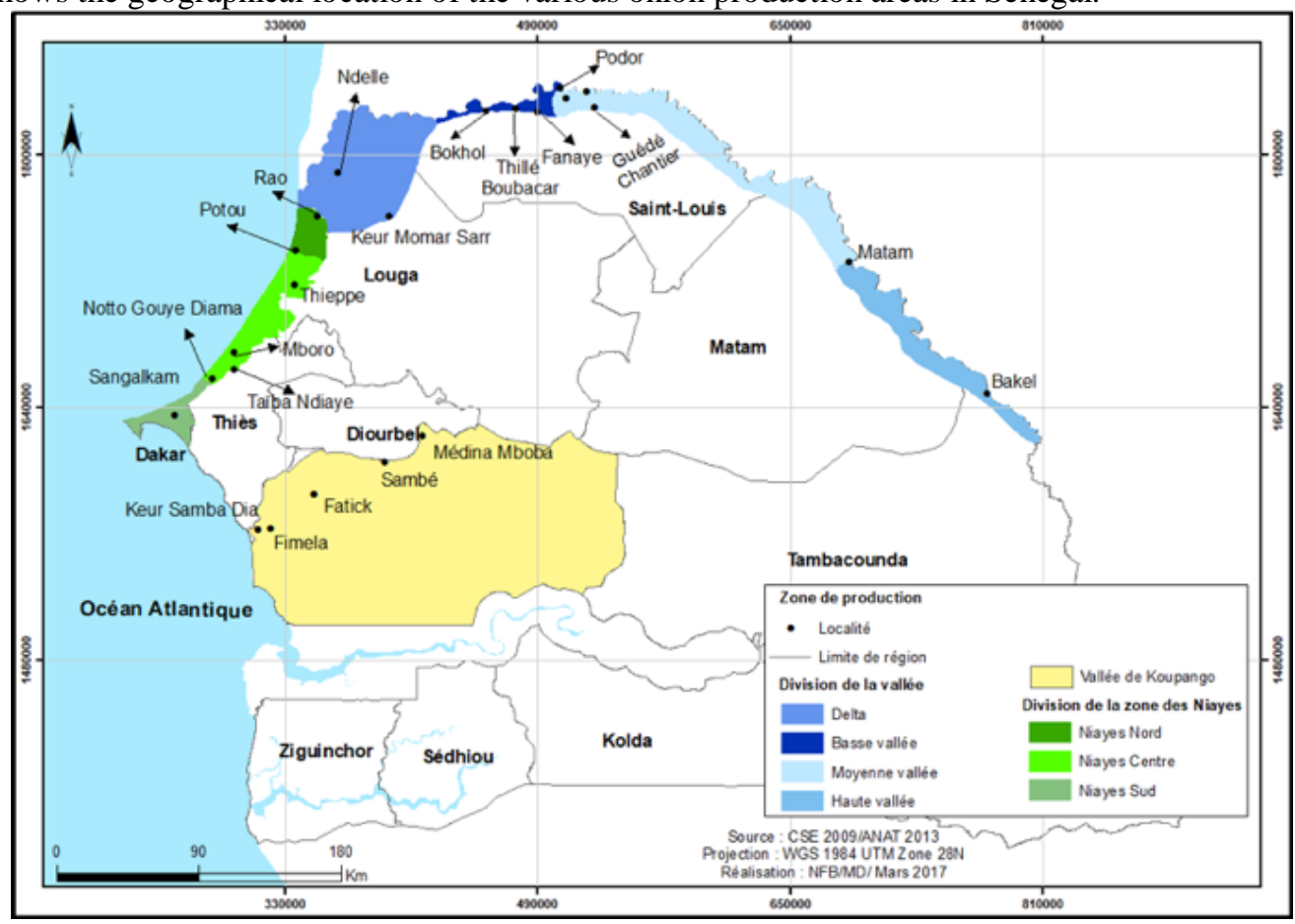

Figure 1:-The main onion production areas in Senegal

According to the various interviews, the Niayes and the Senegal River Valley alone account for between 80 and $85 \%$ of the national production. Over the last six years, the Senegal River Valley comes first before the Niayes (Table 2).

Table 2:-Evolution of onion production in the two main production areas over the last six years

\begin{tabular}{|c|c|c|c|c|c|c|c|}
\hline & & \multicolumn{6}{|c|}{ SEASON } \\
\hline & & 2010/11 & 2011/12 & 2012/13 & 2013/14 & 2014/15 & 2015/16 \\
\hline \multirow{3}{*}{$\begin{array}{l}\text { Senegal } \\
\text { River } \\
\text { Valley }\end{array}$} & Cultivated area (Ha) & 4887 & 3636 & 4402 & 3790 & 5571 & 7368 \\
\hline & Output (Tons/Ha) & 19.89 & 21.63 & 27.21 & 26.97 & 22.54 & 26.19 \\
\hline & Production (Tons) & 93106 & 78650 & 119800 & 102233 & 125558 & 185914 \\
\hline \multirow[t]{3}{*}{ Niayes } & Cultivated area (Ha) & 3460 & 3000 & 3270 & 3376 & 4534 & 5175 \\
\hline & Output (Tons/Ha) & 21.78 & 23.97 & 28 & 27.57 & 25.54 & 25.86 \\
\hline & Production (Tons) & 74700 & 69453 & 89780 & 91600 & 113470 & 133579 \\
\hline
\end{tabular}

In addition, It results from these interviews that in 2016 the Senegal River Valley contributed to the national production (393,225 tons) for seven months (from February to August) up to 47\%, while the contribution of the Niayes spreads over 8 months (from January to August) up to 34\% (Table 2).Harvests are mostly between March 
and May with $80 \%$ of the production of the Senegal River Valley provided by Podor and $65 \%$ of the production of the Niayes covered by Potou.

It should be noted that the existence of multiple varieties with sowing dates from October to April, is an essential lever to overcome seasonality. In fact, if in the Senegal River Valley, only CSC seedlings are practicable, in the Niayes, both types of sowing are made possible by soil and hydro-geological characteristics. Thus, the Niayes zone is a major asset for spreading crops up to 10 months out of 12 (compared to 8 months out of 12 currently observed).

\section{Various Brakes to Self-sufficiency in Onions}

\section{Technical Component}

\section{Production Cost}

In 2009, production costs in Niayes and Senegal River Valley were respectively 100 and 65 FCFA. Since 2016, these costs have decreased to 80 and 55 FCFA.

This difference in cost between the two main production areas is explained by:

1. Community harvesting of the Senegal River Valley lands;

2. Free technical support from SAED to the Senegal River Valley producers for a large-scale sowing (while the Niayes producers individually support the production costs and practice a small-scale sowing due to the lack of technical support);

3. the irrigation cost significantly higher in the Niayes.

In fact, unlike the use of river water as an irrigation source for crops in the Senegal River valley, watering in the Niayes is done with water from the "céanes" (hollow wells), wells, boreholes and even city water for some farmers. Despite the existence of improved varieties with sowing periods between October and April, thus predisposing to staggering crops in Niayes area, Senegalese producers still practice only one season per year (Tropicasem, 2014).This is due to the additional costs related to irrigation in the Niayes area and the lack of technical support in production.

\section{Technical Management and Storage Type}

Stopping growth, especially when the leaves fall at $80 \%$ of maturity, dry out and get brown, triggers the harvest. In so doing, irrigation is stopped when $30 \%$ of the yellow leaves fall. Harvesting does not begin until 10 to 15 days after stopping irrigation. Unfortunately in practice, the start of harvests is guided by the producer's storage capacity but also the importance of its regular incomes (PADEN, 2014).

Figure 2:-presents harvest and post-harvest treatments by storage type.

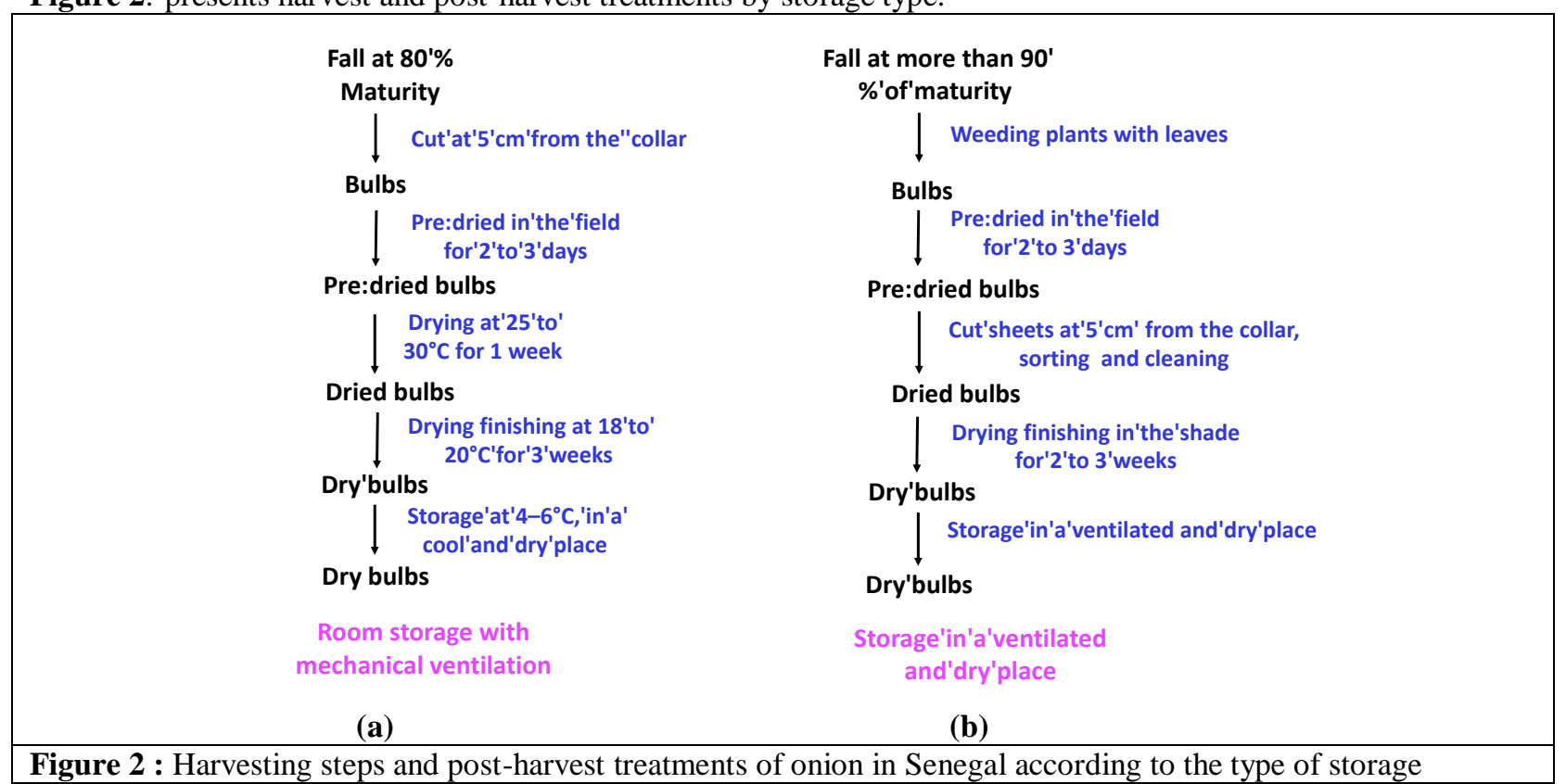


In the West, where producers have drying units with controlled temperatures and hygrometry, harvests are $80 \%$ of fall or less because the collar will be well dried during storage with mechanical ventilation (Figure 2 (a)). Thus, the risk of rot is reduced (Hallouin, Mazollier, \& Ferrera, 2014).

On the other hand, in Senegal, where post-harvest bulb drying is carried out in plots after plucking plants with their desiccated leaves and continues in storage chambers without any control of temperature and humidity, crops are harvested over-mature when all the foliage is lying down (Figure 2 (b)). However, this over-ripening exposes the bulb and causes an attack by fungi (PRODEX, 2012).

It appears that, in addition to the harvest stage and the post-harvest treatments, the storage conditions are also crucial on the storage life and availability of the onion in the market. However, these storage means are insufficient both in number and capacity (Figure 3).

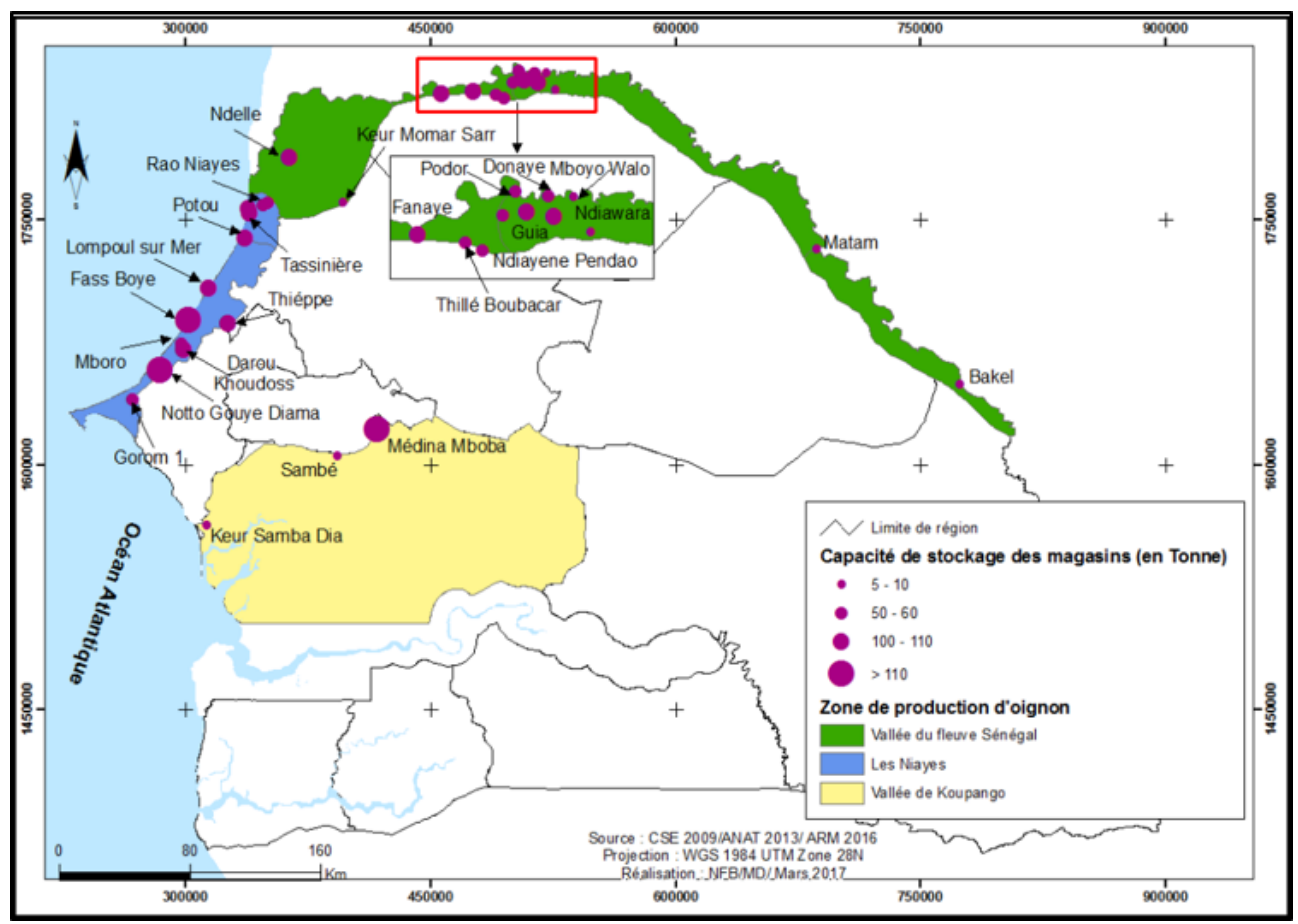

Figure 3:-Location of different storage structures in Senegal. Source : (ARM, 2017)

The total storage capacity in Senegal is approximately 3,535 tons, of which 2,060 tons are in the Niayes, 960 tons in the Senegal River Valley and 515 tons in the Koupango Valley.

The state of the storage structures (Figure 3) reflects an imbalance in the distribution, because the Senegal River Valley, where the production is superior to that of the Niayes in the last six years (Table 2), has a storage capacity half the size. In the Senegal River Valley as well as in the Niayes, the few support structures for the professional organization are not homogeneously distributed. (Podor has two storage structures of 5 tons and one of 50 tons, Potou has 2 areas of 50 tons).

Consequently, the serious insufficiency in dry and well-ventilated storage areas, combined to the non-compliance with crop management techniques and the non-processing of the products, justify the important post-harvest losses estimated at around 5 to $10 \%$ at fields, $20 \%$ during storage for three months and $40 \%$ during storage for six months.

\section{Transformation}

Onion consumption estimated at about $13 \mathrm{~kg} /$ person / year (D'Alessandro \& Soumah, 2008) represents about 25\% of Senegalese households' vegetable expenses. This places Senegal in second rank among onion-eating countries in West Africa, behind Niger (16 kg / person / year). 
The significant post-harvest loss leads some stakeholders to think about potential processing possibilities in order to increase the storage life and, above all, to remedy seasonality (David \& Moustier, 1997). Various ways of valorization exist to date in the literature, among which can be mentioned dehydration and freezing. Dehydrated products available in various forms such as strips, dices, semolina and powder are mainly intermediate products used by the food industry for the manufacture of cold cuts, vegetable soups, soups, chips, and culinary broths. In contrast, frozen products are used both at the household level and by industry.

It is clear that the processing and use of these processed products is widespread in Western countries, but not in Senegal, where bulb are consumed cooked or raw.

Another indirect mode of consumption involves the use of culinary broths (made in Senegal or imported), one of the basic ingredients of which is onion powder. Manufacturers located in Senegal import onion powder because it is not produced locally. This lack of bulbs processing into powder at the local level, is due to two main reasons that are: the lack of mastery of drying techniques while respecting hygiene conditions and the very high cost of the process relating to high energy consumption.

\section{Organizational Component}

\section{The Stakeholders of the Sector}

Since 1998, producers have started to organize themselves around farmers' organizations for a better management of the sector and especially a preferential price fixing for the local onion. Thus, in 1999, the Association of Market Unions of the Niayes (AUMN), and the Association of Onion Producers of the Valley (APOV) were created and became essential in the management of the sector.

The interprofessional body, which was created in 2011, is supported by the Ministry in charge of trade, the informal sector, consumption, the promotion of local products and SMEs, in order to better establish the organization of the subsector. It brings together all the stakeholders in the onion value chain, from the field to the distribution of the product to end-users (Sow, 2006; Wade, 2008).

The stakeholders are mapped according to their functions (Figure 4) at the value chain level as follows:

\section{Support and Accompaniment functions mainly:}

1. Government actors (Ministry of Agriculture and Rural Equipment (MAER), DH, ISRA, Directorate of Plant Protection (DPV), ARM, DCI, SAED, National Agency for Agricultural and Rural Council (ANCAR), Regional Directorates for Rural Development (DRDRD) ...) whose missions include training and consulting, research, regulation and market regulation;

2. Private suppliers of seeds, phytosanitary products, fertilizers and agricultural equipment such as Tropicasem, Agroseed ..., but also public services such as DH and ISRA which actively participate in research programs for the development of varieties better adapted to the climatic conditions of Senegal;

Financing functions, especially financing bodies such as the "Caisse Nationale de Crédit Agricole du Senegal" (CNCAS), the Fund for Guaranteeing Priority Investments (FONGIP), the Federation of Non Governmental Organizations of Senegal (FONGS) ...;

Production functions, ie individual producers or producer groups;

Processing functions of some GIEs (Economic Interest Groupings) that do not master techniques. This link to provide added value and especially reduce post-harvest losses is still in its infancy in Senegal;

Marketing functions (collectors, wholesalers, traders who are rural or urban intermediaries playing a key role in finding potential buyers and negotiating prices, retailers);

Carriers;

End-users, including consumers as well as manufacturers;

Trade unions, including national, regional and local producers' federations, the National Union of Traders and manufacturers of Senegal (UNACOIS). 


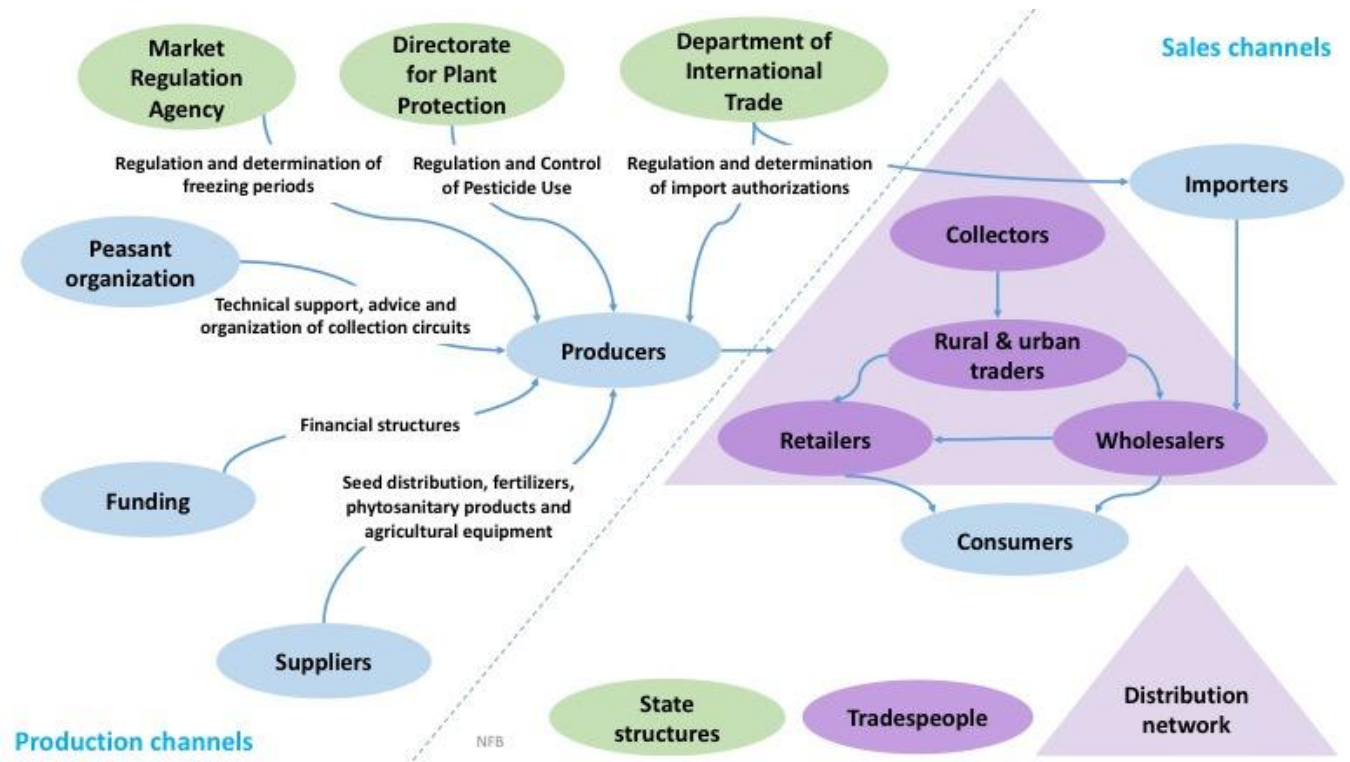

Figure 4:-Mapping of stakeholders in the onion value chain in Senegal

It should be noted that in this non-exhaustive classification exercise, some stakeholders perform multiple functions at different stages of the value chain. The multiplicity of stakeholders and functions (Figure 4), underlies the organizational difficulties of both production and marketing.

\section{Regulatory Framework}

Faced with the instability of the onion market, due to the failure of the organization of the sector, the noncompliance with crop management techniques by producers and the massive importation of onion, the Senegalese government and the stakeholders in the sector have all been working since the 1990s to develop action plans and implement appropriate solutions for better regulation of the market (Duteurtre \& Dieye, 2008). The two flagship measures that have resulted are the periodic freezing of imports and market regulation by prices.

\section{$\Rightarrow \quad$ Freeze Imports}

The difficulties of selling the local onion have always urged Senegal to add a quota to imports. As such, importers have the obligation to market the local onion for one third of the volumes imported. Unfortunately, the accession of Senegal to the World Trade Organization (WTO) in 1995, annihilated the onion quota system.

This liberalization of trade in the agricultural sector increases quickly imports and unsold local onions. For this purpose, as of 1998, the State applies a surtax of 20\% (limited to 30\% maximum) on onions imported outside the WAEMU and ECOWAS zones. The surtax was backed by the special safeguard clause for agriculture defined in the World Trade Organization (WTO) agreements.

Despite the introduction of this protection surtax and the organization of producers for better management of the subsector, the functioning of the markets has not improved significantly. In fact, producers are still faced with the recurrent difficulties to sell the local onion, competing with imported onions for two reasons:

1. Senegalese preference for imported onion, which is of better quality and easier to conserve;

2. Disparate and uncoordinated actions of different stakeholders (Diouf, 2014; Wade, 2008).

The beginnings of regulating onion supply and securing the market (Figure 5) are observed with the creation of the Market Regulation Agency by decree in 2002. 


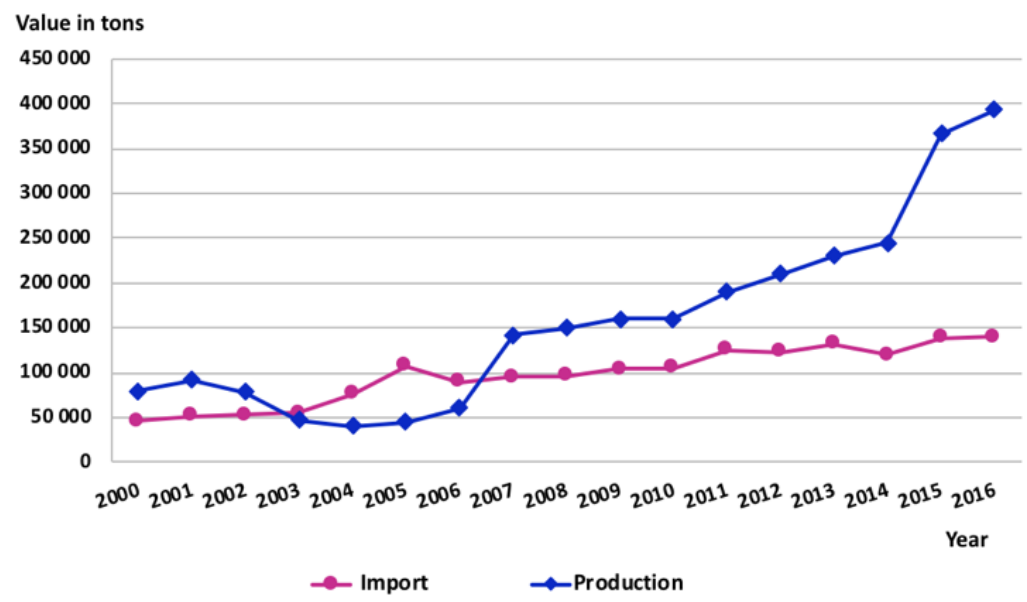

Figure 5:-Evolution of onion imports versus production in Senegal during the period 2000 to 2016. Source:

(FAOSTAT and ANSD, 2016)

At the beginning of 2003, one of the first actions of the Market Regulation Agency (ARM) was the establishment of a national consultation framework gathering all the stakeholders in the sector. Its goal was to offer collegiate solutions to prevent the increase in imports (1.18 times local production) from continuing. In this context, trade resulted in the adoption of a procedure for the freezing of imports during production periods. The freezing procedure became effective from 2004 following a sudden increase in imports and strong deflation of the onion price (Sow, 2006; Wade \& Ndiaye, 2009). Currently, the stakeholders of the sector set production periods and freeze periods during the consultations organized before each campaign.

It is worth noticing that despite the first freeze periods between July and September 2004, the upward trend in imports has continued. The circumvention of the freezing procedure by the constitution of reserve stocks of imported onion before the freeze periods resulted in the simultaneous presence of local onion and imported onion on the market.

In fact, this measure did not have the desired effect, and imports peaked in 2005. To overcome these deficiencies, additional measures were taken in 2005 by the authorities to regulate the onion market. They mainly consisted in getting minutes of inspections by the Directorate of Plant Protection (DPV) and import declarations issued by the Department of Internal Trade (DCI), and in facilitating licenses to importers respecting the obligation to market the local onion and the non transferability of these licenses. These measures have been effective from 2007, year when production rose again above imports.

From 2012, onion production started to develop in a relatively rapid pace with no real impact on the level of imports, which remain stable and have been around 120,000 tons since 2011.

Despite an increase in the freeze period from 3 months at its beginning in 2004 to 7 months in 2009, there was only a slight decrease in imports due mainly to a better control of the crop calendar (staggering of the production from 5 months out of 12 to 7 months out of 12) and the production of quality bulbs that can withstand competition from imported onions.

Noticing the limit of the freezing procedure led to the need to reinforce this measure through intervention by the state and various stakeholders in the value chain for a price regulation.

\section{Attempt to Regulate the Market by a Price Policy}

In order to stabilize the market, a recommended price chart is established by all stakeholders in the value chain before each marketing campaign. This recommended prices chart is of two types: a producer farm-gate price and a consumer price applied in the marketing places. 


\section{Impact of Price Policy on Farm-gate Prices}

So as to limit the impact of import-related unsold products on their incomes, producers were often forced to sell at a loss. Now, the farm-gate prices in the chart ensure protection to producers. In fact, since the implementation of the consultation framework, the evolution of farm-gate prices (Figure 6) shows that the average prices practiced are well above the average prices recommended in the chart, except for the year 2012 when they stood at 162.5 FCFA for a recommended price of 195 FCFA.

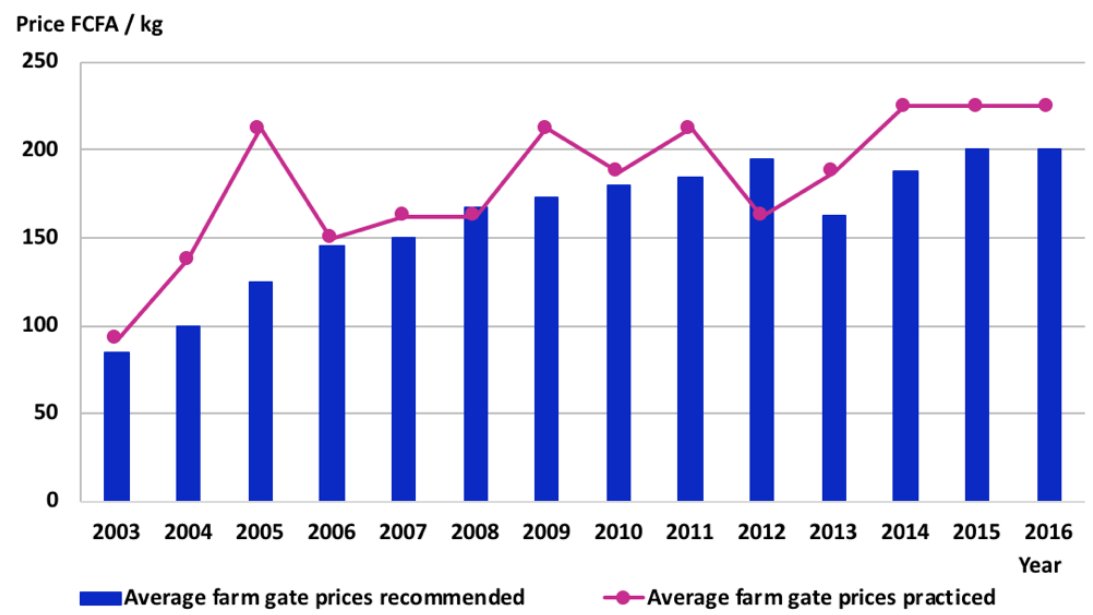

Figure 6:-Evolution of Farm gate Prices since the Creation of the Consultation Framework. Source : (ARM, 2016)

This decrease is explained by the increase of imported onion reserve stocks, competing in this way with the local onion. The import quota system, set up in 2013 to limit this simultaneous presence of local and imported onions, had a positive effect over the last three years with the stabilization of the prices practiced at 225 FCFA (around 25 FCFA above recommended prices).

Overall, the attempts to organize the stakeholders in the subsector and the implementation of the new regulatory framework by ARM, have a positive impact on the evolution of farm-gate prices (Figure 6). However, this evolution remains erratic from one year to the next despite the introduction of freeze periods (freeze period increased from 3 months to 7 months between 2005 and 2009 with a variation of one month each year (ARM, 2015, 2016, 2017) and the establishment of the price charter.

This analysis should be refined to assess the impact of freeze periods on the determination of farm-gate prices in a given year. The deepening of the study, however, depends on the availability of statistical data in embryonic state to date.

\section{Effects of Price Policy on Consumer Prices}

In some parts of Senegal, the price trends charged to consumers (Figure 7) indicates that consumer price differentials are widening in favor of imported onions whose quality is considered as superior to that of local onion. Except for the year 2014 when the average price of the local onion slightly exceeded that of imported onion in the region of Fatick (380 FCFA against 350 FCFA). We also note that consumer prices are quite disparate from one region to another. In fact, average prices fluctuate between 200 and 350 FCFA in the producing regions or near production areas such as Dakar, Thies, Saint-Louis, Louga, Diourbel and Matam, while in regions such as Fatick and Kaolack with fledgling production in the Koupango Valley, prices are between 300 and 379 FCA. In the Kolda and Tambacounda regions, where production is almost non-existent, average prices do not fall below 325 FCFA (325 - 450 FCFA). 

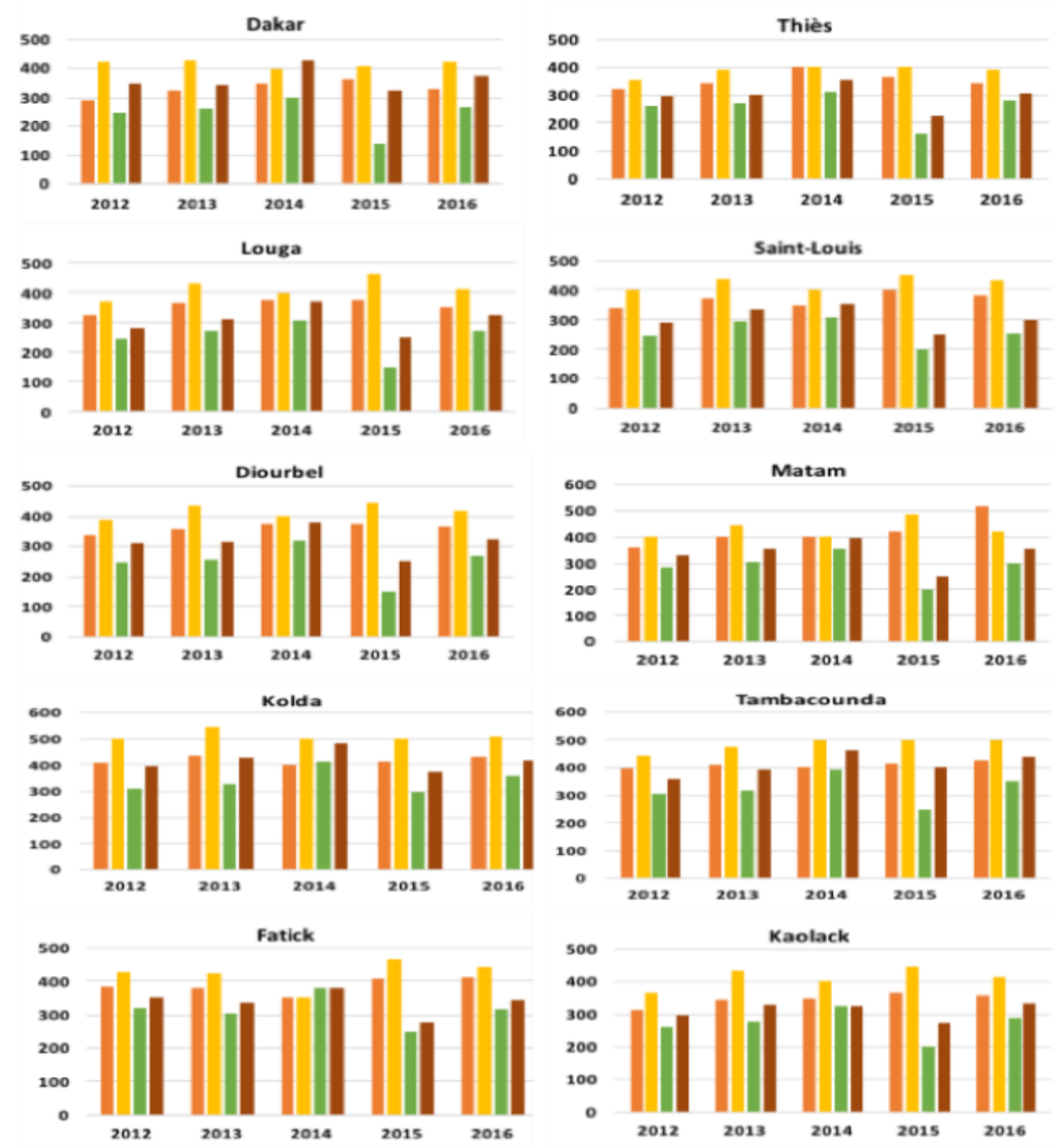

Figure 7:-Evolution of local and imported onion prices in some regions of Senegal (Average annual prices calculated from monthly prices, source ARM)
Imported onion min price,
imported Onion max price
Local onion min price,
local onion max price

This rising trend is attributable to transportation costs and peaks in onion availability. In addition, the significant speculative behaviours during the religious feasts and the simultaneous presence of local and imported onions on the market at early (February-March) and late (July - August - September freeze), also contribute to these prohibitive prices. The attempt to regulate both on-farm and consumer prices is therefore not totally efficient because of the limits of the price chart and its implementation. These limits are related to a lack of control over the production schedules that are highly dependent on the producers' incomes and in the absence of a control system that entails:

1. Inadequate regulation of production periods;

2. A bad compliance with crop management techniques;

3. A simultaneous presence of local and imported onions, despite freeze periods;

4. A lack of reliable statistical data and above all the deficiencies noted in terms of traceability as regards state subsidies and actual campaign expenses.

Despite the beginning of producers' organization and the government's action for market regulation, Senegal is still dependent on imports, thought the production in 2016 reached 393,225 tons covering in this way needs in onion. As a result, the setting up of well-organized collection platforms and marketing channels reducing the multiplicity of stakeholders are decisive levers for the implementation of the pricing policy. 


\section{Conclusion:-}

The situational analysis of Senegal's onion subsector shows that efforts made in terms of agricultural and marketing policies have reached their objectives with a local onion production of 393225 tons in 2016, largely covering consumption needs (150,000 and 250,000 tons). Despite this performance, onion imports of 140,000 tons in 2016 show a persistence of post-harvest losses related to agricultural practices. In fact, the irregularity of producers' incomes contributes to the non-compliance with crop management techniques, which ultimately leads to a decline in onion quality and storage life.

As a result, the sectoring of production areas by period remains an important lever to ensure compliance with crop management techniques affecting the quality and incomes of producers.

It would also ensure annual coverage of consumption needs by local production (coverage which is already 7 months out of 12). This trend can be maintained thanks to the dynamism of national research structures and manufacturers offering improved local varieties that are better adapted to climatic conditions.

The major bottlenecks to achieving real self-sufficiency in onion, one of the main staple foods in Senegal, are storage conditions and processing in order to diversify the product offer and the modes of use. The development of a new link in the value chain, that is the onion processors, would not only contribute to achieving food self-sufficiency in onion, but also improve the competitiveness of the subsector and generate at the same time substantial additional incomes that are crucial in the fight against household vulnerability (referring to the most stringent conditions for 2016 ie 140,000 tons imported, 80 FCFA / kg for the highest cost of production, post-harvest losses of 40\%). Ultimately, effective policies to boost production alone are not enough to meet demand. It is essential to associate them with trade, conservation and processing policies.

\section{References:-}

1. Abdou, R., Bakasso, Y., Adam, T., Saadou, M., \& Baudoin, J.-P. (2015). Biologie, diversité et outils pour l'analyse de la diversité génétique de l'oignon, Allium cepa L. (synthèse bibliographique). Biotechnologie, Agronomie, Société et Environnement, 19 (2), 184-196.

2. ANSD. (2013). Agence Nationale de Statistique et de la Démographie (ANSD): RGPHAE-2013, Résultats définitifs. Consulté 2 mars 2018, à l'adresse http://www.ansd.sn/ressources/RGPHAE2013/ressources/pages/rapports-regionaux.htm website: http://www.ansd.sn/ressources/RGPHAE2013/ressources/pages/rapports-regionaux.htm

3. ANSD. (2016a). Agence Nationale de Statistique et de la Démographie (ANSD) : Collecte d'informations sur les données de production et les prix.

4. ANSD. (2016b). Bulletin Mensuel Situation Économique [Bulletin mensuel]. Agence Nationale de Statistique et de la Démographie.

5. APOV. (2015). Association des Producteurs d'Oignon de la Vallée (APOV): Pratiques agricoles et les conditions de stockage dans la vallée du fleuve Sénégal. Focus group avec les producteurs. .

6. APOV. (2016). Association des Producteurs d'Oignon de la Vallée (APOV): Pratiques agricoles et les conditions de stockage dans la vallée du fleuve Sénégal. Focus group avec les producteurs. .

7. APOV. (2017). Association des Producteurs d'Oignon de la Vallée (APOV): Pratiques agricoles et les conditions de stockage dans la vallée du fleuve Sénégal. Focus group avec les producteurs. .

8. ARM. (2015). Agence de Régulation des Marchés (ARM): Rôles et Impacts des actions de l'Agence de Régulation des Marchés dans l'organisation de la sous-filière oignon au Sénégal. Agence de Régulation des Marchés.

9. ARM. (2016). Agence de Régulation des Marchés (ARM): Rôles et Impacts des actions de l'Agence de Régulation des Marchés dans l'organisation de la sous-filière oignon au Sénégal. Agence de Régulation des Marchés.

10. ARM. (2017). Agence de Régulation des Marchés (ARM): Rôles et Impacts des actions de l'Agence de Régulation des Marchés dans l'organisation de la sous-filière oignon au Sénégal. Agence de Régulation des Marchés.

11. AUMN. (2015). Association des Unions Maraîchères des Niayes (AUMN): conditions de stockage dans la zone des Niayes. Focus group avec les producteurs.

12. AUMN. (2016). Association des Unions Maraîchères des Niayes (AUMN) : conditions de stockage dans la zone des Niayes. Focus group avec les producteurs.

Pratiques agricoles et les

Pratiques agricoles et les 
13. AUMN. (2017). Association des Unions Maraîchères des Niayes (AUMN): Pratiques agricoles et les conditions de stockage dans la zone des Niayes. Focus group avec les producteurs.

14. Cabral, F. J. (2012). Politique commerciale, croissance et réduction de la pauvreté dans les Pays les Moins Avancées : le cas du Sénégal. [Conférence des Nations Unies sur le Commerce et le Développement]. Ministère du Commerce.

15. Currah, L. (2002). 16 Onions in the Tropics: Cultivars and Country Reports. Allium crop science: recent advances, 2, 379.

16. D'Alessandro, S., \& Soumah, A. (2008). Évaluation sous régionale de la chaîne de valeurs oignon/échalote en Afrique de l'Ouest. Bethesda, MD: projet ATP, Abt Associates Inc, 3-72.

17. David, O., \& Moustier, P. (1997). Formation de la qualité dans la filière oignon en Afrique de l'Ouest. Bulletin de Liaison (Coopération Régionale pour le Développement des Productions Horticoles en Afrique), (12), 55-65.

18. Dewez, B., Gerard, M., Delhove, G., \& Dramé, K. A. (2012). Les techniques de production précoce pour l'étalement de la culture de l'oignon au Sénégal Cultures à partir de bulbilles et par semis direct. Réseau Africain pour le Développement de l'horticulture (RADHORT), Organisation des Nations Unies pour l'Alimentation et l'Agriculture (FAO).

19. DH. (2015). Direction de l'Horticulture (DH): Statistiques horticoles. Direction de l'Horticulture.

20. DH. (2016). Direction de l'Horticulture .(DH): Statistiques horticoles. Direction de l'Horticulture.

21. Diouf, M. M. (2014). La filière oignon au Sénégal. (p. 1-11) [Bulletin d'analyse économique]. Centre de Gestion et d'Economie Rurale de la Vallée (CGERV), Saint-Louis.

22. Duteurtre, G., \& Dieye, P. (2008). Les organisations interprofessionnelles agricoles au Sénégal. De nouveaux outils de régulation des marchés. 192 p, 31-37.

23. FAO (Éd.). (2017). Food and Agriculture Organization: Building resilience for food and food security. Rome: FAO.

24. FAOSTAT. (2016). Food and Agriculture Organization Corporate Statstical Database (FAOSTAT). Consulté 2 mars 2018, à l'adresse http://www.fao.org/faostat/fr/\#country/195 website: http://www.fao.org/faostat/fr/\#country/195

25. Gourc, D., Monnier, D., \& Payet, J. D. (2007). Oignon guide pratique, Ile de la réunion, France. Fiche technique (www. armeflhor. fr), 1-61.

26. Hallouin, I., Mazollier, C., \& Ferrera, S. (2014). Fiche culturale : Oignon botte et oignon de conservation. (p. 1-15) [Fiche culturale]. Chambre d'agriculture des Bouches-du-Rhône. Agriculture et Terroir.

27. Hanelt, P. (2018). Taxonomy, evolution, and history. In Onions and allied crops (p. 1-26). CRC Press.

28. Kroll, R. (1994). Les cultures maraîchères. In Le Technicien d'Agriculture Tropicale: Vol. 29 (Editions Maisonneuve et Larose : Centre Technique de Coopération Agricole et rurale (C.T.A.), p. 219). Agence de coopération culturelle et technique. Paris.

29. Luumpa, C. L., Kouassi, R. N., \& Chinganya, O. J. M. (2016). Annuaire Statistique pour l'Afrique. Banque Africaine de Développement (BAD), Commission de l'Union Africaine (CUA) et la Commission Économique des Nations Unies pour l'Afrique (CEA).

30. Niang, Y. (2015). Centre pour le Développement de l'Horticulture (CDH) : Les varités d'oignon les plus cultivées au Sénégal et facteurs inflençant la conservation.

31. PADEN. (2014). Fiche Technique de Bonnes Pratiques de production d'oignon dans les Niayes au Sénégal. (p. 1-6) [Fiche technique]. Programme d'Aménagement et de Developpement Economique des Niayes. Unité de Coordination du Programme (UCP).

32. PRODEX. (2012). Guide des bonnes pratiques de production, de stockage et de conservation de l'oignon. (p. 1-13). Ministère de l'Agriculture du Niger. Pojet de Développement des Exportations et des marchès Agro-Sylco-Pastoraux.

33. Seck, P. A. (2013). Programme d'Accélération de la Cadence de l'Agriculture Sénégalaise (PRACAS). Ministre de l'Agriculture et de l'Equipement Rural du Sénégal.

34. Sow, I. (2006). Etat des lieux de la filière fruits et légumes au Sénégal, Sénégal (p. 5-7; 33-45). Infoconseil, Paoa,Gret, Enda graf, SNC Lavalin, Cintech, MAE, CDE, ACDI, MIA, Dakar,.

35. Tropicasem. (2014). Mieux réussir la culture précoce d'oignon à partir de bulbilles. (p. 2-5) [Mensuel Technique - Tropiculture].

36. Wade, I. (2008). Le cadre de concertation pour la filière oignon. In Duteurtre G. et Dieye P. N. (coordinateurs) : Les organisations interprofessionnelles agricoles au Sénégal: De nouveaux outils de régulation des marchés (p. 111-123). Bureau d'Analyses Macro-Économiques Institut Sénégalais de Recherches Agricoles (ISRA BAME), Dakar.

37. Wade, I., \& Ndiaye, O. S. (2009). La régulation du marché de l'oignon au Sénégal. 48, 1-8. 